\title{
Human T-Lymphotropic Virus Type 1 transcription and chromatin-remodeling complexes
}

\author{
Rebecca Easley ${ }^{1}$, Lawrence Carpio ${ }^{1}$, Irene Guendel ${ }^{1}$, Zachary Klase ${ }^{2}$, Soyun Choi ${ }^{3}$, Kylene Kehn-Hall' \\ Fatah Kashanchi ${ }^{1,3^{*}}$ \\ From 15th International Conference on Human Retroviruses: HTLV and Related Viruses \\ Leuven and Gembloux, Belgium. 5-8 June 2011
}

Human T-lymphotropic virus type 1 (HTLV-1) encodes the viral protein Tax, which is believed to act as a viral transactivator through its interactions with a variety of transcription factors, including CREB and NF- B. As is the case for all retroviruses, the provirus is inserted into the host DNA, where nucleosomes are deposited to ensure efficient packaging. Previous studies using immunoprecipitation from Tax-expressing cells, 2-dimensional gel electrophoresis, and mass spectrometry analysis have identified the ATPase subunit BRG1 as a Tax-interacting protein. BRG1, is part of at least 8 complexes which include BAF and PBAF, as well as WINAC, NCoR, mSin3A/HDAC, and NUMAC. Nucleosomes act as roadblocks in transcription, making it difficult for RNA polymerase II (Pol II) to proceed toward the 3' end of the genome. Our results using HTLV-1 integrated chromatin indicate that the Tax-activated promoter utilized PBAF complex which appears to be responsible for nucleosome remodeling. Also, the promoter was assembled into an ordered array of translationally positioned nucleosomes. In contrast, the inactive promoter was relatively inaccessible to nuclease and was not assembled into a translationally positioned nucleosomal arrays.

\section{Author details}

${ }^{1}$ George Mason University, Department of Molecular and Microbiology,

National Center for Biodefense and Infectious Diseases, Manassas, VA, 20110, USA. ${ }^{2}$ National Institutes of Health, Molecular Virology Section, Laboratory of Molecular Microbiology, NIAID, Bethesda, Maryland, 20892, USA. ${ }^{3}$ The George Washington University Medical Center, Department of Microbiology,

Immunology, and Tropical Medicine, Washington, DC, 20037, USA.

\footnotetext{
* Correspondence: fkashanc@gmu.edu

'George Mason University, Department of Molecular and Microbiology, National Center for Biodefense and Infectious Diseases, Manassas, VA, 20110, USA

Full list of author information is available at the end of the article
}

Published: 6 June 2011

doi:10.1186/1742-4690-8-S1-A178

Cite this article as: Easley et al:: Human T-Lymphotropic Virus Type 1 transcription and chromatin-remodeling complexes. Retrovirology 20118 (Suppl 1):A178.
Submit your next manuscript to BioMed Central and take full advantage of:

- Convenient online submission

- Thorough peer review

- No space constraints or color figure charges

- Immediate publication on acceptance

- Inclusion in PubMed, CAS, Scopus and Google Scholar

- Research which is freely available for redistribution

\section{() Biomed Central}

C Biomed Central

C 2011 Easley et al; licensee BioMed Central Ltd. This is an open access article distributed under the terms of the Creative Commons Attribution License (http://creativecommons.org/licenses/by/2.0), which permits unrestricted use, distribution, and reproduction in any medium, provided the original work is properly cited. 